\title{
Progress of Soybean Charcoal Rot under Tillage and No-tillage Systems in Brazil
}

\author{
Álvaro M. R. Almeida' ${ }^{1}$ Lilian Amorim², Armando Bergamin Filho ${ }^{2}$, Eleno Torres ${ }^{1}$, José R. B. Farias ${ }^{1}$, \\ Luís C. Benato ${ }^{1}$, Mauro C. Pinto ${ }^{1} \&$ Nilson Valentim ${ }^{1}$
}

${ }^{1}$ Embrapa Soja, Cx. Postal 231, 86001-970, Londrina, PR, Brazil, e-mail: almeida@cnpso.embrapa.br; ${ }^{2}$ Setor de Fitopatologia, ESALQ, Cx. Postal 9, CEP 13418-900, Piracicaba, SP, Brazil.

(Accepted for publication on 25/06/2002)

Corresponding author: Álvaro M. R. Almeida

ALMEIDA, A M.R., AMORIM, L., BERGAMIN FILHO, A, TORRES, E., FARIAS, J.R.B., BENATO, L.C., PINTO, M.C. \& VALENTIM, N. Progress of soybean charcoal rot under tillage and no-tillage systems in Brazil. Fitopatologia Brasileira 28:131-135. 2003.

\begin{abstract}
The increase in incidence of charcoal rot caused by Macrophomina phaseolina on soybeans (Glycine max) was followed four seasons in conventional and no-till cropping systems. In the 1997/ 98 and 2000/01 seasons, total precipitation between sowing and harvest reached 876.3 and $846.9 \mathrm{~mm}$, respectively. For these seasons, disease incidence did not differ significantly between the no-till and conventional systems. In 1998/99 and 1999/00 precipitation totaled 689.9 and $478.3 \mathrm{~mm}$, respectively. In 1998/99, in the no-till system, the disease incidence was $43.7 \%$ and $53.1 \%$ in the conventional system. In $1999 / 00$ the final incidence was $68.7 \%$ and $81.2 \%$ for the no-till and conventional systems, respectively. For these two seasons, precipitation was lower than that required for soybean crops (840 $\mathrm{mm}$ ), and the averages of disease incidence were significantly higher

in the conventional system. The concentration of microsclerotia in soil samples was higher in samples collected in conventional system at $0-10 \mathrm{~cm}$ depth. However, analysis of microsclerotia in roots showed that in years with adequate rain no difference was detected. In dry years, however, roots from plants developed under the conventional system had significantly more microsclerotia. Because of the wide host range of $M$. phaseolina and the long survival times of the microsclerotia, crop rotation would probably have little benefit in reducing charcoal rot. Under these study conditions it may be a better alternative to suppress charcoal rot by using the no-till cropping system to conserve soil moisture and reduce disease progress.

Additional keywords: Macrophomina phaseolina, disease progress curves, microsclerotia.
\end{abstract}

\section{RESUMO}

Progresso da podridão de carvão em raízes de soja nos sistemas de semeadura convencional e direta no Brasil

$\mathrm{O}$ aumento da incidência da podridão de carvão, causada por Macropphomina phaseolina, em raízes de soja, foi avaliada durante quatro anos, nos sistemas de semeadura direta (SD) e convencional (SC). Em 1997/98 e 2000/01, a precipitação total entre a semeadura, em novembro, e a colheita, em março, foi de 876.3 e $846.9 \mathrm{~mm}$, respectivamente, não havendo diferença significativa entre a incidência na SD e SC. Em 1998/99 e 1999/00, a precipitação observada foi de 689.9 e $478.3 \mathrm{~mm}$, respectivamente. Em 1998/99, a incidência final nos sistemas de SD e SC foi de $43,7 \%$ e $53,1 \%$, respectivamente. Em 1999/00, a incidência final foi de 68,7\% e 81,2\%. Nesses dois anos, considerados secos (precipitação pluviométrica <
$840 \mathrm{~mm}$ ), as médias de incidência entre os dois sistemas de semeadura foram significativamente diferentes $(\mathrm{P}=0,05 \%)$. A concentração de microesclerócios de raízes e de solo, coletados à profundidade de 0 $10 \mathrm{~cm}$ em SD e SC, mostrou resultados diferentes. Amostras de solo de SC sempre apresentaram maior concentração de microesclerócios do que amostras de $\mathrm{SD}(\mathrm{P}=0,05 \%)$. No entanto, amostras de raízes não apresentaram a mesma resposta. Em anos secos, a concentração foi maior na soja do SC. Não houve diferença em anos com boa precipitação. Devido ao grande número de plantas hospedeiras e à sobrevivência dos microesclerócios no solo, não se acredita que a rotação de culturas seja adequada no controle dessa doença. Entretanto, a manutenção de umidade, favorecida pelo sistema de SD, parece reduzir o progresso da doença, favorecendo o controle do fungo.

\section{INTRODUCTION}

Charcoal rot caused by Macrophomina phaseolina (Tass.) Goid. is the most common root disease found in soybean [Glycine max (L.) Merril] fields in Brazil (Wrather et al., 1997). It used to be considered a secondary pathogen since its effects were mainly observed at the final stages of the crop; however, the disease can appear at any stage of plant growth (Machado, 1987). In Brazil, charcoal rot is frequently associated with periods of drought. Losses in yield to $50 \%$ have been experienced in northern parts of the State of Paraná (Ferreira et al., 1979). In the USA, losses up to $20 \%$ have been reported (Sinclair \& Gray, 1972). Macrophomina phaseolina was considered a secondary pathogen since its effects were mainly observed at the final stages of the crops; however the disease can appear at any 
stage of plant growth (Machado, 1987).

The fungus is considered to be a soil-borne pathogen and is able to infect several plants such as cotton (Gossypium hirsutum L.), peanut (Arachis hypogaea L.), corn (Zea mays L.), sunflower (Helianthus annuus L.), sorghum [Sorghum bicolor (L.) Moench], etc. (Ghaffar \& Zentmyer, 1968;Figueiredo et al., 1969). The most practical and costeffective method to control this disease is the use of resistant cultivars. Recently, Smith \& Carvil (1997) were able to identify four cultivars rated as moderately resistant.

One alternative control for this disease could be the use of crop rotation. However, this fungus attacks a wide range of host plants, and it has the ability to survive and to multiply in crop residues (Pearson et al., 1984; Almeida et al., 2001). Another alternative control practice could be management of the soil to interfere with the biology or survival of the pathogen by altering the environment or to favor antagonists. According to Kendig et al. (1989), irrigation reduced the severity of charcoal rot in soybeans.

In Brazil, soil management has been characterized mainly by conventional tillage. In recent years, the use of notill systems has increased and reached nine million ha (Saturnino, 1998). One significant factor that affects soil fertility is the retention of crop residues on the surface of the soil to reduce soil erosion. Continuous production of soybean in no-till fields results in an accumulation of plant residue, which is reported to mainly favor aerial diseases and that is an important drawback for the no-till system. Unfortunately, not much research has been conducted to evaluate the effect of conservation tillage on soil-borne diseases.

Wrather et al. (1998) made a comparison of three tillage systems to study the effect on the population density of M. phaseolina. After a 3-year study, they concluded that long-term tillage did not affect the incidence of charcoal rot on soybean. This conclusion may not be applicable to Brazilian conditions, where the crop is cultivated under tropical and subtropical conditions either in conventional or no-till systems. Almeida (2001) concluded that the survival of $M$. phaseolina was favored by buried residues of soybean plants but no evaluation was made on the effect of tillage system on the infection of soybean roots.

The objective of this research was to determine the type of disease progress in soybean root systems. Epidemics of charcoal rot were compared in conventional and no-till systems during four consecutive years.

\section{MATERIAL AND METHODS}

The experiment was established in a field in which conventional tillage and no-till systems were used at the same location for 16 consecutive years. The soil was classified as an Oxisol, Haplorthox (American Soil Taxonomy), with 67\% clay, $17 \%$ silt, and $16 \%$ sand in the Ap horizont. The climate is defined as Cfa according to Koeppen cited by Strahler (1975). Disease severity in soybean roots of cultivar Embrapa 48 was evaluated by analysis of root fragments during four seasons (1997/98, 1998/99, 1999/00 and 2000/01). Planting dates were: 11/14/1997, 11/11/1998, 11/06/1999 and 11/14/ 2000. Plots were $7 \mathrm{~m}$ wide and $10 \mathrm{~m}$ long with seven rows spaced by $0.6 \mathrm{~m}$. Five plants from each plot were dug at random from each of the four replicate plots in each conventional and no-till systems at different periods during the season. Twenty roots from each treatment (conventional tillage and no-till) were washed with a brush in running water to remove adhering soil, and the roots were subsequently dried with paper towels. From each root, four fragments $(5 \mathrm{~mm}$ long) were randomly cut, disinfected in $50 \%$ alcohol for 30 $\mathrm{s}$, transferred to sodium hypochloride $(0.5 \%)$ for $1 \mathrm{~min}$ and rinsed in sterile water. Fragments from each plant were placed in one Petri plates that contained potato-dextrose-agar plus streptomycin sulfate $(0.1 \mathrm{~g} / \mathrm{l})$. Plates were incubated in darkness at $26^{\circ} \mathrm{C}$ for seven days. The percentage of infection for each root was determined through identification of those $5 \mathrm{~mm}$ fragments with $M$. phaseolina. The incidences of infected fragments were used to get the area under disease progress curve (Shaner \& Finney, 1977) for the percentage of infected roots.

Assessment of the colonization of host tissue was done immediately after harvest, usint the procedures used by Smith $\&$ Carvil (1997). Five plants in each plot were chosen at random and these plants were dug, washed, and dried. Secondary roots and taproots were removed and ground in a cyclone mill and these powdered root masses were thoroughly mixed. A sample of $0.2 \mathrm{~g}$ of the powder was mixed with 100 $\mathrm{ml}$ of semi-selective media (Mihail \& Alcorn, 1982) and divided among five Petri plates. Plates were incubated in darkness at $28^{\circ} \mathrm{C}$ for nine days. The number of colony-forming units (cfu) were counted with stereoscopic microscope to determine the population of cfu's per gram [???] of air-dried root tissue.

Soil was sampled at sowing and at the R5 stage (Fehr et al., 1971). Five soil cores (2.5 cm diameter) were removed from the top $10 \mathrm{~cm}$ of soil from each plot along diagonals. Cores were bulked, dried at room temperature and screened through a no. 10 screen $(2 \mathrm{~mm}$ opening). Densities of microsclerotia were estimated according to Mihail and Alcorn (1982) for a 5-g portion of sieved soil based on the number of cfu per gram of air-dried soil.

Overall intensities of epidemics were evaluated by the areas under the disease progress curve (AUDPC) based on the percentage of infected roots using Tukey's test. Meteorological data were provided by an automatic weather station (Campbell Sci., Inc., Logan, UT, USA) located in the experimental field.

\section{RESULTS AND DISCUSSION}

Macrophomina phaseolina infected roots were found in the very early stages of growth of the soybean plants in both, no-till and conventional tillage systems. In general, the number of infected roots increased over time (Figure 1). However, taproots collected shortly after sowing always 
Progress of soybean charcoal rot under tillage and no-tillage...

showed a reddish brown discoloration of vascular tissue when the roots were cut longitudinally. In very few cases, plants with infected roots exhibited the traditional symptoms of dead leaves that remained attached to the petioles.

In the 1998/99 and 1999/2000 crop seasons, the AUDPCs for the no-till system were significantly lower $(P=$ 0.05 ) than for the conventional system (Table 1). In the 1997/ 1998 and 2000/2001 seasons, there was no significant difference in the AUDPCs between the two systems. Although precipitation was higher in 1997/98 and 2000/2001 (Table $1)$, there was no correlation $(P>0.1)$ between disease severity or AUDPC and the total amount of rain. Many microsclerotia were found both inside and outside the epidermis, but only in evaluations made near harvest. For densities of microsclerotia, taproots were collected immediately after harvest in the years of $1999 / 00$ and 2000/2001. There were significantly fewer microsclerotia in the no-till plots (Table 2). Considerably more microsclerotia were found in or on roots in the season 2000/ 2001 than in the season 1999-2000. The amount of rain measured during the crop season was $876.3 \mathrm{~mm}, 689.9 \mathrm{~mm}$, $478.3 \mathrm{~mm}$ and $846.9 \mathrm{~mm}$ for the $1997 / 2001$ period, respectively. Soil surface temperatures measured in the conventional system were 4 to $5^{\circ} \mathrm{C}$ higher than those observed in the no-till system (Table 3 ). On the contrary, reflectance measured before the soybean canopy had closed was always higher in no-till plots. Both no-till and conventional systems had wheat in the winter season. This double-crop practice is used by most of the farmers in the southern parts of Brazil. The wheat straw was left on the soil surface to conserve soil moisture and to prevent erosion.

The fast increase in the area of soybeans grown under the no-till system in Brazil has not been accompanied by the

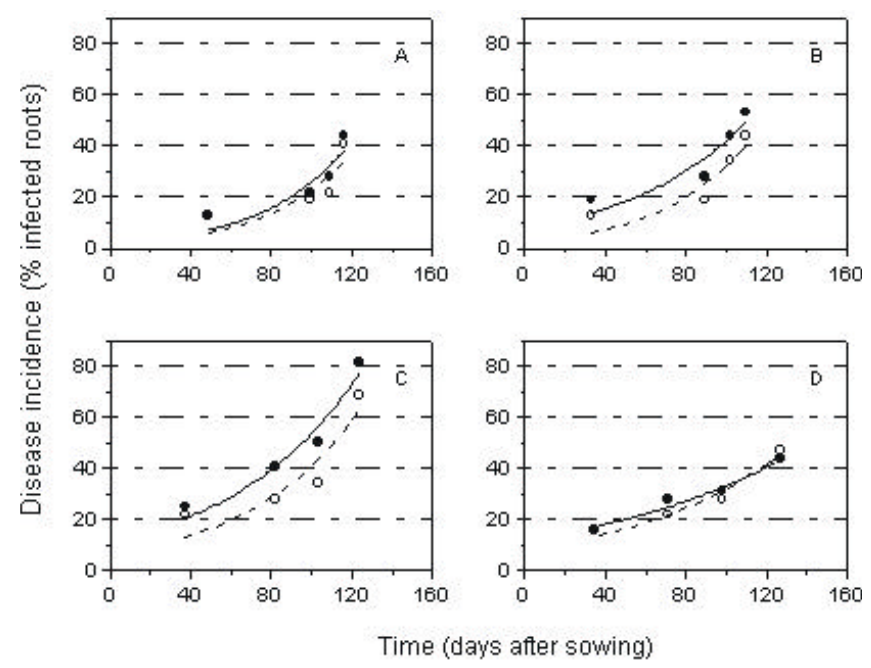

FIG. 1 - Impact of cropping systems on the percentage of infected soybean (Glycine max) roots by Macrophomina phaseolina over four years. Values plotted obtained from the mean of 20 roots. Solid lines = conventional system; segmented lines = no tillage . Amount of rain in each year. $\mathrm{A}=1997 / 98,876,3 \mathrm{~mm} ; \mathrm{B}=1998$ / 99, 689,9 mm; $C=1999 / 2000,478,3 \mathrm{~mm} ; \mathrm{D}=2000 / 01,846,9 \mathrm{~mm}$.
TABLE 1 - Area under the disease progress curves (AUDPC) for four epidemics of charcoal root caused by Macrophomina phaseolina under conventional and no tillage system, in four different years and different total amounts of rain in each season (mm)

\begin{tabular}{lccc}
\hline \hline \multirow{2}{*}{ Year } & \multicolumn{2}{c}{ Tillage system* } & \multirow{2}{*}{ Rain (mm) } \\
\cline { 2 - 3 } & Conventional & No-tillage & \\
\hline $1997 / 1998$ & $935.94 \mathrm{a}$ & $940.63 \mathrm{a}$ & 876,3 \\
$1998 / 1999$ & $1118.75 \mathrm{a}$ & $850.00 \mathrm{~b}$ & 689,9 \\
$1999 / 2000$ & $2189.06 \mathrm{a}$ & $1764.06 \mathrm{~b}$ & 474,3 \\
$2000 / 2001$ & $1637.50 \mathrm{a}$ & $1518.75 \mathrm{a}$ & 846,9 \\
\hline
\end{tabular}

*Values within a row followed by different letters differ significantly $(\mathrm{P}<0.05)$ according to Tukey's test.

TABLE 2 - Densities of microesclerotia of Macrophomina phaseolina in soybean (Glycine max) roots and soil samples and disease severity observed at harvest in plants developed under no-tillage and conventional systems

\begin{tabular}{lcccc}
\hline \hline Treatment & \multicolumn{2}{c}{ Microesclerotia density* } & \multicolumn{2}{c}{$\begin{array}{c}\text { Disease severity* } \\
\text { (\% Infected roots) }\end{array}$} \\
\hline Root** & $1999 / 00$ & $2000 / 01$ & $1999 / 00$ & $2000 / 01$ \\
No till & $149.0 \mathrm{~b}$ & $138.9 \mathrm{a}$ & $68.75 \mathrm{~b}$ & $46.88 \mathrm{a}$ \\
Conventional & $290.3 \mathrm{a}$ & $183.5 \mathrm{a}$ & $81.25 \mathrm{a}$ & $43.75 \mathrm{a}$ \\
\hline Soil*** & $1999 / 00$ & $2000 / 01$ & & \\
No till & $26.4 \mathrm{a}$ & $73.8 \mathrm{a}$ & & \\
Conventional & $27.2 \mathrm{a}$ & $59.5 \mathrm{a}$ & & \\
\hline
\end{tabular}

*Values within a column followed by different letters differ significantly $(\mathrm{P}<0.05)$ according to Tukey's test.

$* * \mathrm{cfu} / \mathrm{g}$ evaluated in $0.25 \mathrm{~g}$ of ground roots.

$* * * \mathrm{cfu} / \mathrm{g}$ soil evaluated in $5 \mathrm{~g}$ of soil at $0-10 \mathrm{~cm}$ depth.

TABLE 3 - Temperature at the soil surface $\left({ }^{\circ} \mathrm{C}\right)$ and albedo* measured in conventional and no-tillage systems

\begin{tabular}{lccc}
\hline \hline Treatment & Date & $\begin{array}{c}\text { Soil surface } \\
\text { temperature }\end{array}$ & Albedo (\%) \\
\hline Conventional & $12 / 11 / 98$ & $74.71 \pm 2.35$ & 9.5 \\
No-tillage & & $70.17 \pm 5.00$ & 17.86 \\
Conventional & $11 / 30 / 99$ & $58.54 \pm 2.37$ & 11.89 \\
No-tillage & & $53.21 \pm 2.62$ & 17.96 \\
\hline *Albedo= ratio between reflected radiation and incidence radiation $\times 100$
\end{tabular}

*Albedo $=$ ratio between reflected radiation and incidence radiation $\mathrm{x} 100$.

same increase in the development of measures for disease control. Many questions have been asked about the effect of crop residues on the soil surface upon the survival of plant pathogens.

Most of the effects of no-till are related to wind-borne pathogens. In Brazil, one of the most important diseases in soybean is charcoal rot (Ferreira et al., 1979; Wrather et al., 1997). Charcoal rot is normally associated with dry weather and high soil temperature during the growing season (Cook et al., 1973; Meyer et al., 1974). In Brazil, this disease was first reported to infect common beans (Phaseolus lunatus L.) in 1935 (Bittancourt, 1935). Very little is known about the behaviour of $M$. phaseolina in tropical soils under no-till or conventional systems in relation to disease severity or 
pathogen survival.

Control of charcoal rot by different methods, such as crop rotation (Francl et al., 1988) and irrigation (Kendig et al., 2000), has been tried. However, since M. phaseolina is a soil-borne pathogen and is able to infect several plant species, crop rotation may not be very beneficial. According to Dhingra\& Sinclair (1978), susceptible crops such as corn and soybeans cropped for three years increased the number of sclerotia. On the other hand, Chattopadhayay \& Mustafe (1977) reported the reduction of $M$. phaseolina inoculum when crop rotation was conducted with pea (Pisum sativum L.) or rice (Oryza sativa L.) between two soybean seasons. Short et al. (1980) observed that $M$. phaseolina survived well in soybean residue. There was a rapid increase in the number of sclerotia in the soil after susceptible crops, such as corn and soybean, were planted. They suggested that the control of this fungus should be achieved by techniques other than crop rotation.

In this 4-year study, it was found that the percentage of infected roots was significantly higher in plants developed under the conventional system, when the year was considered dry for the soybean crop ( $<840 \mathrm{~mm}$ of rain) under Brazilian conditions (Berlato \& Bergamaschi, 1979). This conclusion was based on the results obtained in 1998/99 and 1999/ 2000. Additionally, there was a delay in root infection in soybean plants grown under the no-till system compared to plants developed under the conventional system Higher densities of microesclerotia in roots were found in plots under conventional tillage. Kendig et al. (2000) reported that irrigation reduced the severity of charcoal rot in soybeans. They also observed that low soil moisture caused a significant increase in infection of soybean root and that the densities of microesclerotia in the roots increased after irrigation had terminated. In our study, however, early infection of soybean roots did not seem to be related to water stress, since rains were common at sowing time. Based on the AUDPC and the rate of increase of infected roots during the four yearly trials, we concluded that the effect of water stress and conventional tillage favored infection of roots by M. phaseolina.

Although high temperature has been mentioned as a factor that predisposes plants to infection by M. phaseolina (Bruton et al., 1987), low soil moisture may be the most important factor for infection. Edmunds (1964) made a similar observation with $M$. phaseolina on sorghum. Ghaffar \& Erwin (1969) and Reuveni et al. (1982) reported that low soil moisture that led to drought stress was considered more important than high temperatures to predispose plants to charcoal rot.

Soybean roots infected by M. phaseolina were observed as early as 30 days after sowing, which is in agreement with Bruton et al. (1987). They also mentioned that infection of cantaloupe (NOME CIENTÍFICO E AUTORIDADE?) roots by $M$. phaseolina did not require drought stress and high temperature for early infection. Disintegration of the epidermis of soybean roots and formation of microsclerotia was observed only after the R2 stage (Fehr et al., 1971). In two years, there were more microsclerotia in roots from the conventional system than from the no-till system, which confirms the effect of soil management on the survival of M. phaseolina. In the season of 2000/2001, the concentration of microsclerotia in the soil was higher under the conventional system than under no-till, which was in contrast to the previous year when the number of microesclerotia were more numerous in the no-till plots. However, the disease severity did not correlate well with the inoculum concentration for both tillage systems. In years with no water stress, a concentration of high inoculum did not induce more infection.

According to Olaya \& Abawi (1996), M. phaseolina can grow and produce large quantities of sclerotia under low water potentials. The no-till system contributes to less drought stress and this may be responsible for lower disease severity in this system. In years with adequate moisture supply, no difference between conventional and no-till systems was observed. The conventional system clearly favored infection of soybean roots when a drought period occurred during the crop season.

Tillage has also been considered an important factor in the spread of fungal propagules in the soil.

Wrather et al. (1998) did not observe differences in incidence of charcoal rot in soybeans grown under disk-till, no-till, and moldboard plow treatments. One possible explanation could be the occurrence of significant drought during the period of our study that could have contributed to differentiate the systems. Also, there were great differences in the edapho-climatic conditions at the location of their study compared to our location.

Macrophomina phaseolina cannot be eliminated from the soil and it constitutes an annual potential threat to soybean production in the tropics depending on the water stress. Some control of charcoal rot may be achieved with a no-till system, when it provides enough soil coverage to reduce moisture loss. Temperature measured at the soil surface was lower in the no-till system. Also, more light interception was observed in no-till system. Both variables may have contributed to keep higher moisture in the no-till system, and thus decrease disease severity.

For tropical countries, where drought may occur more frequently, the no-till system may help to avoid losses caused by $M$. phaseolina. However, other diseases can be favored by this system that will require additional practices to control diseases, such as crop rotation and sowing a less susceptible plant species.

\section{AKNOWLEDGMENTS}

The authors thank Dr. Richard Berger (University of Florida), Dr. Ademir Henning (Embrapa Soja) and Dr. Flávio Moscardi (Embrapa Soja), Dr. Carlos A. Lopes (Embrapa Hortaliças) for useful comments on the manuscript. This paper was approved for publication by the Editorial Board of Embrapa Soja as manuscript \#20/2001. 
Progress of soybean charcoal rot under tillage and no-tillage...

\section{LITERATURE CITED}

ALMEIDA, A.M.R. Estudo preliminar da sobrevivência de patógenos de soja em restos de cultura coletados nos sistemas de plantio direto e convencional. Resultados de Pesquisa de Soja. 1979/ 80. Embrapa Soja. 1980. pp.113-115.

BAIRD. R.E., MULLINIX. B.G., PEERY. A.B. \& LANG. M.L. Diversity and longevity of the soybean debris mycobiota in a notillage system. Plant Disease 81:530-534. 1997.

BERLATO, M.A. \& BERGAMASCHI, H. Water consumption by soybeans:I. Seasonal evapotranspiration in conditions of optimal water availability in soil. Anais 1 Seminário Nacional de Pesquisa de Soja, Londrina, 1979.

BITTANCOURT, A.A. Uma nova doença do feijão. O Biológico 1:41. 1935.

BRUTON, B.D., JEGER, M.J. \& REUVENI, R.M. Macrophomina phaseolina infection and vine decline in cantaloupe in relation to planting date, soil environment, and plant interaction. Plant Disease 71:259-263, 1987.

CHATTOPADHAYAY, S.B. \& MUSTAFE, T.P. Inoculum potential influencing pathogenicity of Macrophomina phaseolina causing seedling blight of jute. Science \& Culture 43:546-548. 1977.

COOK, G.E., BOOSALIS, M.G., DUNKLE, L.D. \& ODOVODY, G.N. Survival of Macrophomina phaseolina in corn and sorghum stalk residue. Plant Disease Report 57:873-875. 1973.

DHINGRA, O.D. \& SINCLAIR, J.B. Biology and pathology of Macrophomina phaseolina. Universidade Federal de Viçosa, 1978.

EDMUNDS, L.K. Combined relation of plant maturity, temperature and soil moisture to charcoal stalk-rot development in grain sorghum. Phytopathology 54:514-517. 1964.

FEHR, W.R., CAVINESS, C.E., BUTWOOD, D.T. \& PENNINGTON, J.S. Stage of development descriptions for soybeans, Glycine max (L.) Merr. Crop Science 11:929-931. 1971. FERREIRA, L.P., LEHMAN, P.S. \& ALMEIDA, A.M.R. Doenças da soja no Brasil. Londrina, PR, Embrapa, Circular técnica. 1979. FIGUEIREDO, M.B., TERANISHI, J. \& CARDOSO, R.M.G. Incidência de Macrophomina phaseolina em feijoeiro e outras plantas cultivadas. O Biológico 35:105-109. 1969.

FRANCL, L.J., WYLLIE, T.D. \& ROSENBROCK, S.M. Influence of crop rotation on population density of Macrophomina phaseolina in soil infested with Heterodera glycines. Plant Disease 72:760764. 1988.

GHAFFAR, A. \& ZENTMYER, G.A. Macrophomina phaseolina on some new weed hosts in California. Plant Disease Report 52:223. 1968.

GHAFFAR, A. \& ERWIN, D.C. Effect of soil water stress on root rot of cotton caused by Macrophomina phaseolina. Phytopathology 59:795-797. 1969.

KENDIG, S.R., RUPE, J.C. \& SCOTT, H.D. Effect of irrigation and soil water stress on densities of Macrophomina phaseolina in soil and roots of two soybean cultivars. Plant Disease 84:895-900. 2000.

MACHADO, C.C. Macrophomina phaseolina: biological behavior of isolates, spatial pattern of microesclerotia in the soil, and incidence on soybeans. (PhD thesis) University of Illinois, Urbana Champaign. 1987.

MEYER, W. A., SINCLAIR, J.B. \& KHARE, M.N. Factors affecting charcoal rot of soybean seedlings. Phytopathology 64:845-849. 1974.

MIHAIL, J.D. \& ALCORN, S.M. Quantitative recovery of Macrophomina phaseolina sclerotia from soil. Plant Disease 66:662663. 1982.

OLAYA, G. \& ABAWI, G.S. Effect of water potential on mycelial growth and on production and germination of sclerotia of Macrophomina phaseolina. Plant Disease 80:1347-1350. 1996.

PEARSON, C.A.S., SCHWENK, F.W., CROWE, F.J \& KELLEY, K. Colonization of soybean roots by Macrophomina phaseolina. Plant Disease 68:1086-1088. 1984.

REUVENI, R., KRIKUN, J., NACHMIAS, A. \& SHELVIN, E. The role of Macrophomina phaseolina in a collapse of melon plants in Israel. Phytoparasitica 10:51-56. 1982.

KENDIG, S.R., RUPE, J.C.\& SCOTT, H.D. Effect of irrigation and soil water stress on densities of Macrophomina phaseolina in soil and roots of two soybean cultivars. Plant Disease 84:895-900.2000.

SATURNINO, H.M. O plantio direto como promotor da qualidade ambiental e prosperidade na agricultura. In:O agronegócio brasileiro:desafios e perspectivas. Sociedade Brasileira de Economia e Sociologia Rural. 1:105-115. 1998.

SHORT, G.E., WYLLIE, T.D. \& BRISTOW, P.R. Survival of Macrophomina phaseolina in soil and residue of soybean. Phytopathology 70:13-17.1980.

SHANER, G. \& FINNEY, R.E. The effect of nitrogen fertilization on the expression of slow-mildewing resistance in Knox wheat. Phytopathology 67:1051-1056. 1977.

SINCLAIR, J.B. \& GRAY, L.E. Three fungi that can reduce soybean yields. Illinois Research 14:5. 1972.

SMITH, G.S. \& CARVIL, O.N. Field screening of commercial and experimental soybean cultivars for their reaction to Macrophomina phaseolina. Plant Disease. 81:363-368. 1997.

STRAHLER, A.N. Classification of global climates. In: Physical geography. 4 ed. New York, John Wiley, 1975. Part III, Chapter 14, pp.243-245.

WRATHER, J.A., ANDERSON, T.R., ARSYAD, D.M., GAI, J., PLOPER, D.L., PORTA-PUGLIA, A., RAM, H.H. \& YORINORI, J.T. Soybean disease loss estimates for the top 10 soybean producing countries in 1994. Plant Disease 81:107-110. 1997.

WRATHER, J.A., KENDIG, S.R. \& TYLER, D.D. Tillage effects on Macrophomina phaseolina population density and soybean yield. Plant Disease 82:247-250. 1998. 